\title{
FRAKSI ETANOL EKSTRAK KULIT DURIAN (Durio zibethinus L.) SEBAGAI ANTIFUNGI TERHADAP Trichophyton mentagrophytes DAN Candida albicans
}

\author{
Ethanol Fraction Durian Skin Extract (Durio Zibethinus L.) As An Antifungi On Trichophyton \\ Mentagrophytes And Candida Albicans
}

\author{
Yuli Wahyu Tri Mulyani, Subur Widodo, Lisa Selviani \\ Fakultas MIPA, Jurusan Farmasi Universitas Tulang Bawang Lampung \\ Email : Yuliwahyu.bio@gmail.com \\ 081368165354
}

\begin{abstract}
Durian is a fruit that is in demand by the community, but during durian season environmental problems arise due to waste from skin of durian. The aimed of the study was to prove the antifungal activity of the ethanol fraction of durian skin against Trichophyton mentagrophytes and Candida albicans and to determine the active active compounds inhibiting $T$. mentagrophytes and C. albicans fungi. Durian skin was extracted by maceration method, then fractionated used ethanol, chloroform, and n-hexane solvents. Ethanol fraction was tested on $T$. mentagrophytes and $C$. albicans fungi used the disc method with a concentration of $10 \%, 20 \%, 40 \%, 60 \%, 80 \%, 100 \%$, distilled water as a negative control, ketoconazole as a positive control. The best inhibition zone is fungi T. mentagrophytes concentration $100 \%$ ( $9.23 \mathrm{~mm})$ negative control $(0 \mathrm{~mm})$, positive control $(32.96 \mathrm{~mm})$, fungi C. albicans the best inhibition zone is concentration of $100 \%(8.30 \mathrm{~mm})$, positive control $(17.17 \mathrm{~mm})$ negative controls $(0 \mathrm{~mm})$. The ethanol fraction was screened by the Thin Layer Chromatography method and positively contained flavonoids ( $r f$ 0.7), tannins (rf 0.58), saponins (If 0.76) and alkaloids (rf 0.64). Minimum Inhibitory Concentrations of $T$. mentagrophytes were $7 \%$ and C. albicans were $8 \%$. The most effective active compound growht of $T$. mentagrophytes is tannins ( $r f 0.7$ ) and for $C$. albicans is flavonoid ( $r f 0.6$ ). The ethanol fraction of durian bark extract has antifungal activity against $T$. mentagrophytes and C. albicans.
\end{abstract}

Keywords: Antifungi, Candida albicans, ethanol fraction skin of durian, Trichophytonmentagrophytes

\begin{abstract}
Abstrak
Durian merupakan buah yang diminati masyarakat, namun saat musim durian masalah lingkungan muncul akibat limbah kulit durian. Tujuan penelitian untuk membuktikan aktivitas antifungi fraksi etanol kulit durian terhadap Trichophyton mentagrophytes dan Candida albicans dan untuk mengetahui senyawa aktif yang aktif menghambat fungi $T$. mentagrophytes dan $C$. albicans. Kulit durian diekstraksi dengan metode maserasi, kemudian difraksinasi menggunakan pelarut etanol, kloroform, dan n-heksan. Fraksi etanol diuji terhadap fungi $T$. mentagrophytes dan $C$. albicans menggunakan metode cakram dengan konsentrasi $10 \%, 20 \%, 40 \%, 60 \%, 80 \%, 100 \%$, akuades sebagai kontrol negatif, ketokonazole sebagai kontrol positif. Zona hambat terbaik fungi T. mentagrophytes yaitu : konsentrasi $100 \%(9,23 \mathrm{~mm})$ kontrol negatif $(0 \mathrm{~mm})$, kontrol positif $(32,96 \mathrm{~mm})$, fungi $C$.
\end{abstract}


albicans zona hambat terbaik konsentrasi $100 \%(8,30 \mathrm{~mm})$, kontrol positif $(17,17 \mathrm{~mm})$ kontrol negatif $(0 \mathrm{~mm})$. Fraksi etanol diskrining dengan metode Kromatografi Lapis Tipis dan positif mengandung flavonoid ( $\mathrm{rf} 0,7)$, tanin (rf 0,58 ), saponin $(0,76)$ dan alkaloid( rf 0,64 ). Konsentrasi Hambat Minimum T. mentagrophytes sebesar $7 \%$ dan C. albicans sebesar $8 \%$. Senyawa aktif yang paling efektif menghambat pertumbuhan fungi $T$. mentagrophytes ( $\mathrm{rf}$ 0,7 ) adalah tanin dan untuk $C$. albicans adalah flavonoid (rf 0,6). Fraksi etanol ekstrak kulit durian memiliki aktivitas antifungi terhadap T. mentagrophytes dan C. albicans.

Kata kunci : Antifungi, Candida albicans, fraksi etanol kulit durian, Trichophyton mentagrophytes

\section{PENDAHULUAN}

Durian (Durio zibethinus L.) merupakan buah yang banyak diminati masyarakat, dan menurut riset badan statistik pada tahun 2014 di Provinsi Lampung produksi buah durian menghasilkan 44.298 ton, dari segi struktur buah durian terdiri dari tiga bagian, yaitu bagian dari daging durian sekitar 20-30\%, biji durian sekitar 5$15 \%$ dan bagian terbesar adalah kulit durian sekitar $60-75 \%$.

Saat musim durian masalah lingkungan muncul akibat limbah kulit durian yang dianggap tidak memiliki nilai ekonomis. Namun kulit durian merupakan salah satu potensial alam yang dapat dimanfaatkan. Penggunaan kulit durian secara tradisional oleh masyarakat digunakan untuk menggusir nyamuk dan serangga juga dapat digunakan untuk menggobati bisul [1].

Pemanfaatan kulit durian dapat digunakan sebagai antibakteri, antiinflamasi dan antioksidan. Ekstrak etanol kulit durian memiliki aktivitas antibakteri yang baik terhadap Pseudomonas aeruginosa dengan kadar hambat minimum sebesar $4 \%$. Senyawa kimia yang terdapat pada kulit durian adalah flavonoid, tanin, saponin, dan alkaloid. Sehingga kulit durian dapat menjadi alternatif pengobatan antifungi [2]. Antifungi merupakan senyawa yang dapat membunuh atau menghambat fungi penyebab infeksi [3].
Penyakit infeksi yang disebabkan fungi masih merupakan masalah yang sulit diatasi. Fungi lebih dapat bertahan pada keadaan alam sekitar yang tidak menguntungkan dibandingkan jasad renik yang lain. Salah satu infeksi fungi disebabkan oleh Candida albicans adalah kandidiasis. Orangorang dengan gangguan sistem kekebalan tubuh menurun sering menderita kandidiasis yang menyebar keseluruh tubuhnya. Infeksi pada vagina yang disebabkan oleh Candida sp. Sekitar $85-90 \%$ sel ragi yang diisolasi dari vagina merupakan spesies C. albicans [4].

Selain infeksi kandidiasis, beberapa jenis penyakit yang terdapat pada manusia dapat disebabkan oleh jenis fungi lain salah satunya Trichophyton mentagrophytes yang merupakan fungi penyebab penyakit kurap. Penyakit kurap adalah infeksi pada permukaan kulit yang disebabkan oleh T. mentagrophytes. Penyakit ini dikenal juga dengan sebutan ringworm, membentuk pinggiran yang jelas seperti sarang cacing berbentuk cincin [5].

Penelitian sebelumnya telah dilakukan penghambatan fungi mentagrophytes menggunakan ekstrak kulit durian pada tingkat konsentrasi yang berbeda dengan hasil dapat menghambat pada konsentrasi $10 \%$ dengan zona hambat sebesar $2.08 \mathrm{~mm}$ [6]. Penelitian lain yang juga telah dilakukan adalah penghambatan fungi $C$. albicans 
menggunakan ekstrak kulit durian pada tingkat konsentrasi yang berbeda dengan hasil dapat menghambat pada konsentrasi $15 \%$ dengan zona hambat sebesar $6.9 \mathrm{~mm}$ [2]. Uji skrining fitokimia terhadap ekstrak kulit durian ditemukan senyawa tanin, alkaloid, saponin, flavonoid [1].

Berdasarkan uraian tersebut peneliti tertarik untuk melanjutkan dari ekstrak ketingkat fraksinasi. Fraksinasi merupakan pemisahan senyawa yang sesuai dengan kepolarannya. Pelarut etanol yaitu pelarut polar yang biasa digunakan untuk menarik senyawa polar yang dapat menarik senyawa flavonoid, saponin, tanin dan alkaloid [1]. Penelitian dengan judul "fraksi etanol ekstrak kulit durian (D. zibethinus L.) sebagai antifungi terhadap $T$. mentagrophytes dan $C$. albicans dengan bioautografi" penting untuk dilakukan.

\section{METODE PENELITIAN Alat dan Bahan}

Alat yang digunakan pada penelitian ini adalah cawan petri, jangka sorong, rotary evaporator, mikro pipet, jarum ose, tabung reaksi, rak tabung reaksi, inkubator, erlenmeyer, gelas ukur, timbangan analitik, lemari pendingin, gelas piala, botol gelap, kertas saring, autoklave, benang kasur, label, kapas, kasa, hote plate, blank cakram dan batang pengaduk.

Bahan yang digunakan pada penelitian ini adalah kulit buah durian, etanol $70 \%$, media SDA, media SDB, aquadest, ketokonazol, kloroform, nheksan, biakan fungi $C$. albicans dan T. Mentagrophytes, amoniak $\left(\mathrm{NH}_{3}\right)$, $\mathrm{FeCl}_{3}$, Liebermann burchard, dan Bourchadat.

\section{Determinasi}

Determinasi kulit dilakukan di Fakultas Biologi Universitas Lampung. Uji ini bertujuan untuk membuktikan bahwa jenis tanaman yang digunakan dalam penelitian telah sesuai dengan yang dimaksudkan, sehingga tidak terjadi kesalahan penggunaan tanaman.

\section{Pembuatan Simplisia Kulit Durian}

Kulit durian masih segar diambil sebanyak $7 \mathrm{~kg}$ dibersihkan dari kotoran, kemudian dicuci dengan air mengalir, ditiriskan lalu dirajang kecil. Biji kabau selanjutnya dikeringkan dibawah sinar matahari dan ditutup dengan kain berwarna gelap hingga kering. Simplisia kering disimpan dalam wadah bersih.

\section{Uji Karakteristik Non Spesifik Simplisia}

Pengujian karakteristik simplisia yang akan dilakukan meliputi uji parameter non spesifik, batas minimal standar uji yang akan dilakukan adalah tiga pengujian antara lain kadar air, kadar abu dan kadar abu yang tidak larut dalam asam [7] .

\section{Penetapan Kadar Air}

Masukkan lebih kurang 10 gram simplisia dan ditimbang dan timbang seksama dalam wadah yang telah ditara. Kemudian cawan dan sampel dikeringkan pada suhu $105^{\circ} \mathrm{C}$ selama 5 jam, didinginkan dan ditimbang, lanjutkan pengeringan dan timbang pada jarak 1 jam sampai perbedaan antara 2 penimbangan berturut-turut tidak lebih dari 0,25\%, kadar air tidak lebih dari 10\% [7]. Kadar air dapat dihitung menggunakan rumus :

$\underline{\text { berat awal simplisia - rerata penimbangan }}$ berat simplisia

\section{Penetapan Kadar Abu}

Lebih kurang 2-3 gram yang telah digerus dan ditimbang seksama, masukkan kedalam krus silikat yang telah dipijarkan, lalu ratakan. Sampel dipijarkan perlahan-lahan sampai arang habis, dinginkan, timbang. Jika cara ini arang tidak dapat dihilangkan, saring dengan kertas saring bebas 
abu. Pijarkan hingga bobot tetap, kemudian timbang. Hitung kadar abu yang tidak larut dalam asam terhadap bahan yang dikeringkan diudara, kadar abu tidak lebih dari 8,6\% [7]. Kadar abu dapat dihitung menggunakan rumus :

$$
\text { Kadar abu }=\frac{\text { Berat Abu }}{\text { Berat Simplisia }} 100 \%
$$

\section{Penetapan Kadar Abu yang Tidak Larut dalam Asam}

Abu yang diperoleh pada penetapan kadar abu, didihkan dengan $25 \mathrm{~mL}$ $\mathrm{HCl}$ encer selama 5 menit, kumpulkan bagian yang tidak larut dalam asam, saring dengan kertas saring, cuci dengan air panas, pijarkan hingga bobot tetap. Hitung kadar abu yang tidak larut dalam asam terhadap bahan yang telah dikeringkan diudara, kadar abu yang tidak larut asam tidak lebih dari 2,9\% [7]. Kadar abu yang tidak larut asam dapat dihitung menggunakan rumus :

abu tidak larut asam $=\frac{\text { Berat abu }}{\text { Berat Simplisia }} 100 \%$

\section{Ekstraksi dan Fraksinasi Kulit Durian}

Ekstraksi menggunakan metode maserasi, simplisia yang digunakan yaitu $500 \mathrm{~g}$ dan perendaman dalam proses maserasi menggunakan pelarut etanol $70 \%$. Fraksinasi menggunakan metode cair-cair.

\section{Pembiakan Fungi}

Biakan diperbanyak dengan menginokulasi inokulum pada media SDA miring. Setelah itu, diinkubasi selama 48 jam pada suhu $37^{\circ} \mathrm{C}$ [8].

\section{Pembuatan Suspensi Fungi}

Fungi $C$. albicans dan $T$. mentagrophytes yang telah diinkubasi diambil 1 mata ose lalu diencerkan dengan $\mathrm{NaCl}$ sebanyak $10 \mathrm{~mL}$ aduk sampai homogen [8].

\section{Uji Daya Antifungi}

Pengujian uji daya antifungi menggunakan metode cakram. Media yang digunakan adalah media SDA. Media yang sudah memadat, goreskan suspensi jamur $C$. albicans dan $T$. mentagrophytes kedalam media SDA secara merata. Kertas cakram yang telah dicelupkan selama 1-2 jam kedalam bahan uji dengan beberapa konsentrasi diletakkan pada lempeng agar yang telah ditanami fungi. Satu kertas cakram pada tiaptiap konsentrasi diletakkan pada cawan petri, termasuk kontrol negatif dan kontrol positif diletakkan pada cawan yang berbeda. Diinkubasi selama 2 hari pada temperatur $37^{\circ} \mathrm{C}$ dan diamati serta ukur zona hambat yang terbentuk disekitar cakram dengan menggunakan jangka sorong [8].

\section{Uji Konsentrasi Hambat Minimum}

Siapkan tabung reaksi yang berisi media SDB 1,9 mL yang mengandung larutan uji pada beberapa konsentrasi terkecil yang memberikan daya hambat pada uji daya antifungi dan 0,1 $\mathrm{mL}$ suspensi fungi. Selain itu disiapkan juga tiga tabung reaksi sebagai kontrol media berisi $2 \mathrm{~mL}$ media SDB, kontrol larutan uji berisi $2 \mathrm{~mL}$ media SDB yang mengandung larutan uji dan kontrol fungi berisi $1,9 \mathrm{~mL}$ media SDB dan 0,1 $\mathrm{mL}$ suspensi fungi.

Masing-masing fungi dari media diinkubasi selama 48 jam pada suhu $37^{\circ} \mathrm{C}$, pengamatan dilakukan dengan membandingkan kekeruhan media. Cairan didalam tabung yang tidak menunjukkan pertumbuhan fungi pada konsentrasi larutan uji terkecil diambil menggunakan jarum ose, kemudian digoreskan kedalam cawan petri yang berisi media SDA tanpa larutan uji, 
setelah itu diinkubasi selama 48 jam pada suhu $37^{\circ} \mathrm{C}$. pengamatan dilakukan dengan melihat atau tidaknya pertumbuhan fungi. Jika terdapat pertumbuhan fungi bersifat fungistatik, sedangkan jika tidak terdapat pertumbuhan fungi bersifat fungisid [8].

\section{Pemisahan Senyawa Secara Kromatografi Lapis Tipis (KLT)}

Uji kandungan senyawa dengan KLT. Fase diam yang akan digunakan yaitu plat silika gel $\mathrm{G}_{60} \mathrm{~F}_{254}$ dengan ukuran 7 $\mathrm{cm} \times 2,5 \mathrm{~cm}$ yang diaktifkan terlebih dahulu dengan pemanasan dalam oven pada suhu $100 \stackrel{\circ}{\circ}$ selama 30 menit. Fase gerak yang digunakan yaitu kloroform : metanol : air dengan perbandingan $\quad(2: 5: 3) \quad(\mathrm{v} / \mathrm{v} / \mathrm{v}))$. Kemudian plat silika ditotolkan sampel menggunakan pipa kapiler sebanyak 5 kali penotolan. Plat silica dibiarkan beberapa menit hingga kering dan dimasukkan ke dalam chamber yang telah jenuh dengan fase gerak yang digunakan. Noda yang tampak pada kromatogram kemudian diamati pada UV dengan panjang gelombang 254 $\mathrm{nm}$ dan $366 \mathrm{~nm}$, kemudian dihitung nilai Rf-nya [9].

Bercak dideteksi dengan pereaksi semprot Bouchardat untuk alkaloid dan akan menunjukkan warna coklat, amonia untuk flavonoid menunjukkan warna kuning, hijau, coklat atau merah muda, $\mathrm{FeCl}_{3}$ untuk tanin akan menghasilkan warna hijau, merah, ungu, biru atau hitam kuat, dan Liebermann-Burchard untuk saponin [9].

\section{Pengujian Secara KLT-Bioautografi}

Senyawa aktif yang mempunyai aktivitas antifungi kemudian dideteksi menggunakan metode bioautografi terlebih dahulu plat diaktifkan. Fraksi ditotolkan sebanyak $15 \times$ pada lempeng KLT ukuran $7 \times 2,5 \mathrm{~cm}$ menggunakan pipa kapiler, biarkan beberapa menit hingga kering dan dimasukkan kedalam chamber yang sudah jenuh dengan fase gerak Cairan lempeng dibiarkan terelusi sampai fase gerak mencapai batas yang diinginkan. Lempeng dikeluarkan dari bejana, kemudian ditempelkan pada permukaan media agar dalam petri yang masing-masing telah diinokulasi dengan suspensi fungi $C$. albicans dan Trichophyton mentagrophytes. Setelah 3 jam lempeng tersebut diangkat dan dipindahkan kemudian diinkubasi pada suhu $37^{\circ} \mathrm{C}$ selama 48 Jam lalu diamati zona hambatan yang terbentuk hitung nilai $\mathrm{Rf}$ nya [9]

\section{Analisis Data}

Data yang diperoleh kemudian dianalisis menggunakan analysis of variance (ANOVA) dan terdapat perbedaan nyata maka dilakukan uji lanjut, uji lanjut yang digunakan yaitu uji Tukey untuk melihat perbedaan pada setiap konsentrasi. Analisis data dengan bantuan software SPSS versi 24.

\section{HASIL DAN PEMBAHASAN}

\section{Determinasi Tanaman Kulit Durian}

Hasil determinasi kulit durian yang dilakukan di Laboratorium Botani Jurusan Biologi Fakultas MIPA Universitas Lampung menunjukan bahwa tanaman yang digunakan adalah benar spesies Durio zibethinus L. dari suku Malvaceae buahnya berbentuk bulat, bulat telur hingga lonjong dengan panjang dan diameter masing-masing $20 \mathrm{~cm}$ dan $25 \mathrm{~cm}$. Kulit buahnya tebal dan permukaan kulitnya bersudut tajam.

\section{Uji Karakteristik Simplisia}

Pengujian karakteristik simplisia yang telah dilakukan adalah uji parameter non spesifik simplisia, batas minimal uji adalah tiga pengujian meliputi kadar air simplisia, kadar abu dan 
kadar abu yang tidak larut asam. Hasil pengujian karakteristik non spesifik simplisia dapat dilihat pada Tabel 1.

Tabel 1. Hasil uji karakteristik simplisia

\begin{tabular}{c|c|c}
\hline Parameter & Hasil & Syarat [7] \\
\hline Kadar Air & $7,8 \%$ & $<10 \%$ \\
\hline Kadar Abu & $4,6 \%$ & $<8,6 \%$ \\
\hline $\begin{array}{c}\text { Kadar Abu Tidak } \\
\text { Larut Asam }\end{array}$ & $2,0 \%$ & $<2,9 \%$ \\
\hline
\end{tabular}

Penentuan kadar air simplisia bertujuan untuk memberikan batasan minimal atau rentang tentang besarnya kandungan air didalam bahan. Pengujian kadar air menggunakan metode gravimetri, kadar air kulit durian yang diperoleh sebesar $7,8 \%$ kadar air tersebut telah memenuhi mutu standar simplisia yang telah ditetapkan yaitu kurang dari $10 \%$. Penentuan kadar abu dan kadar abu tidak larut asam bertujuan untuk memberikan gambaran kandungan mineral internal dan eksternal yang berasal dari awal sampai terbentuknya ekstrak. Kadar abu yang diperoleh sebesar $4,6 \%$, hasil yang diperoleh telah memenuhi standar mutu simplisia yang ditetapkan yaitu $8,6 \%$. Kadar abu tidak larut asam simplisia kulit durian telah memenuhi standar yaitu diperoleh hasil sebesar $2 \%$ standar yang ditentukan yaitu tidak lebih dari $2,6 \%$. Simplisia yang telah melewati uji karakteristik simplisia memenuhi standar yang telah ditetapan ini membuktikan bahwa simplisia kulit durian adalah simplisia yang memiliki kadar air dan kandungan mineral internal dan eksternal yang baik [7].

\section{Ekstraksi dan Fraksinasi Kulit Durian}

Pelarut yang digunakan yaitu etanol dengan konsentrasi $70 \%$ karena pelarut akan menembus dinding sel dan masuk kedalam rongga sel yang mengandung zat aktif. Pelarut etanol memiliki sifat yang mampu melarutkan hampir semua zat, baik polar dan yang bersifat nonpolar serta kemampuannya untuk mengendapkan protein dan menghambat kerja enzim sehingga terhindar dari proses hidrolisis dan oksidasi [10]. Ekstrak yang diperoleh yaitu $250 \mathrm{~mL}$ ekstrak cair. Ekstrak yang diperoleh difraksinasi dengan pelarut etanol (polar), kloroform ( semi polar ) dan nheksan ( non polar ) fraksinasi dilakukan sampe pelarut bening dan diperoleh $45 \mathrm{~mL}$ fraksi etanol kulit durian pekat.

\section{Hasil Uji Daya Antifungi}

Uji daya antifungi fraksi etanol ekstrak kulit durian yang telah dilakukan terhadap dua fungi yang berbeda yaitu $T$. mentagrophytes dan $C$. albicans. Hasil pengujian dapat dilihat pada gambar 1 dan gambar 2 sebagai berikut.

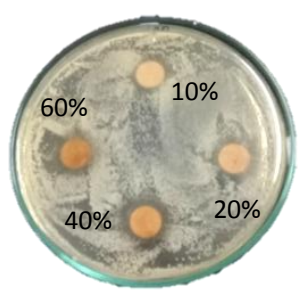

(A)

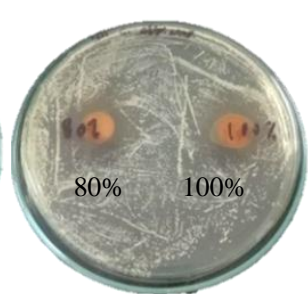

(B)

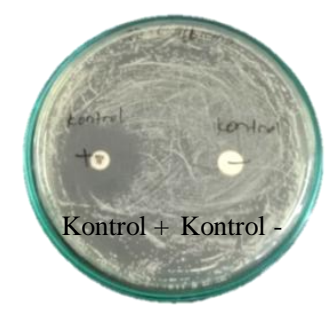

(C)

Gambar 1. Uji daya antifungi C.albicans (A) konsentrasi $10 \%, 20 \%, 40 \%$ dan $60 \%$ (B) konsentrasi $80 \%$ dan $100 \%$ (C) kontrol - dan kontrol + 


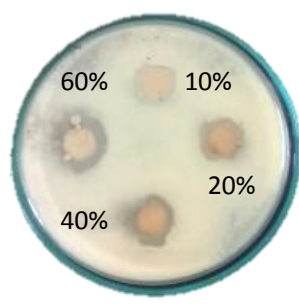

(A)

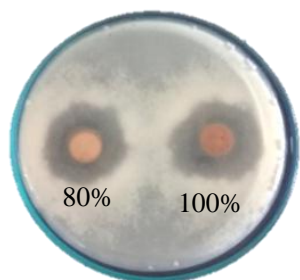

(B)

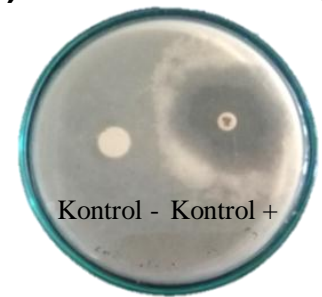

(C)

Gambar 2. Uji daya antifungi T.mentagrophytes (A) konsentrasi 10\%, 20\%, $40 \%$ dan $60 \%$ (B) konsentrasi $80 \%$ dan $100 \%$ (C) kontrol - dan kontrol +

Hasil penggujian antifungi fraksi etanol ekstrak kulit durian terhadap $T$. mentagrophytes dan C. albicans terbukti bahwa fraksi etanol ekstrak kulit durian dapat menghambat pertumbuhan fungi uji, terlihat dari terbentuknya zona bening disekitar cakram. Konsentrasi terkecil yang membentuk zona hambat untuk fungi T. mentagrophytes dan C. albicans adalah pada konsentrasi $10 \%$ dan konsentrasi terbesar terbentuknya zona hambat adalah pada konsentrasi $100 \%$, sedangkan zona hambat terbesar yang terbentuk dari setiap perlakuan untuk kedua fungi uji adalah kontrol positif. Hasil uji antifungi fraksi etanol ekstrak kulit durian terhadap $T$. mentagrophytes dan $C$. albicans dapat dilihat pada Tabel 2 .
Tabel 2. Diameter zona hambat T. mentagrophytes dan Candida albicans

\begin{tabular}{cccc}
\hline Fungi & Perlakuan & $\begin{array}{c}\text { Rata-rata } \\
\text { Zona Hambat } \\
\text { ( } \mathbf{m m})\end{array}$ & $\begin{array}{c}\text { Respon } \\
\text { Hambatan }\end{array}$ \\
\hline T. mentagrophytes & $40 \%$ & $3,47 \pm 04^{\circ}$ & Lemah \\
& $10 \%$ & $1,38 \pm 0,03^{\mathrm{a}}$ & Lemah \\
& $60 \%$ & $4,82 \pm 07^{\circ}$ & Lemah \\
& $80 \%$ & $8,12 \pm 0,12^{\mathrm{d}}$ & Sedang \\
& $100 \%$ & $9,23 \pm 0,9^{\circ}$ & Sedang \\
$\mathrm{K}+$ & $32,96 \pm 0,08^{\mathrm{f}}$ & Sangat Kuat \\
$\mathrm{K}-$ & $0 \pm 0,00^{\mathrm{g}}$ & Tidak Ada \\
\hline C. albicans & $10 \%$ & $2,76 \pm 0,35^{\mathrm{a}}$ & Lemah \\
& $20 \%$ & $4,46 \pm 0,40^{\mathrm{b}}$ & Lemah \\
$40 \%$ & $5,70 \pm 0,27^{\circ}$ & Sedang \\
& $60 \%$ & $6,50 \pm 0,23^{\circ}$ & Sedang \\
& $80 \%$ & $7,14 \pm 0,41^{\circ}$ & Sedang \\
$100 \%$ & $8,30 \pm 0,15^{\circ}$ & Sedang \\
& $\mathrm{K}+$ & $17,17 \pm 0,35^{\mathrm{f}}$ & Kuat \\
$\mathrm{K}-$ & $0 \pm 0,00^{\circ}$ & Tidak Ada \\
\hline
\end{tabular}

Diameter zona hambat fungi $T$. mentagrophytes yaitu pada konsentrasi $10 \%$ sebesar $1,38 \mathrm{~mm}$ dengan respon hambatan lemah, konsentrasi $20 \%$ sebesar $2,80 \mathrm{~mm}$ respon hambatan lemah, konsentrasi $40 \%$ zona hambat terbentuk sebesar $3,47 \mathrm{~mm}$ dengan respon hambatan lemah, konsentrasi $60 \%$ sebesar 4,82 $\mathrm{mm}$ memiliki respon hambatan lemah, konsentrasi $80 \%$ terbentuk zona hambat sebesar $m 8,12 m$ dengan respon hambatan sedang dan konsentrasi $100 \%$ zona hambat terbentuk sebesar 9,23 $\mathrm{mm}$ dengan respon hambatan sedang. Penelitian ini menggunakan kontrol positif ketokonazol pada fungi $T$. mentagrophytes rata-rata zona hambat yang terbentuk yaitu 32,96 $\mathrm{mm}$ dan memiliki respon hambatan sangat kuat sedangkan kontrol negatif menggunakan akuades dan tidak terbentuk zona hambat pada sekitar cakram dan memiliki respon hambatan tidak ada. Konsentrasi $100 \%$ fraksi etanol kulit durian dibandingkan dengan kontrol positif ketokonazole tidak lebih baik menghambat $T$. mentagrophytes. 
Rata-rata zona hambat yang terbentuk pada fungi $C$. albicans pada konsentrasi $10 \%$ adalah sebesar 2,76 $\mathrm{mm}$ dan konsentrasi $20 \%$ sebesar 4,46 $\mathrm{mm}$ kedua konsentrasi ini memiliki respon hambatan lemah. Konsentrasi $40 \%$ rata-rata zona hambat yang terbentuk adalah sebesar $5,70 \mathrm{~mm}$ dan memiliki respon hambatan sedang, konsentrassi $60 \%$ sebesar $6,50 \mathrm{~mm}$ respon hambatan sedang. Konsentrasi $80 \%$ dan $100 \%$ berturut-turut terbentuk zona hambat dengan rata-rata sebesar $7,14 \mathrm{~mm}$ dan $8,30 \mathrm{~mm}$, kedua konsentrasi ini memiliki respon hambatan sedang. Fungi uji $C$. albicans menggunakan kontrol positif ketokonazole terbentuk rata-rata zona hambat sebesar 17,17 $\mathrm{mm}$ dan memiliki respon hambatan kuat, kontrol negatif menggunakan akuades, pada kontrol negatif tidak terbentuk zona hambat disekitar cakram dengan respon hambatan tidak ada. Konsentrasi fraksi etanol $100 \%$ di bandingkan dengan kontrol positif lebih baik kontrol positif dalam menghambat fungi $C$. albicans.

Setelah diperoleh data diameter zona hambat dilakukan uji statistik. Hasil dari uji homogenitas diperoleh data yang homogen, nilai signifikan yang diperoleh lebih besar dari 0,05 yaitu sebesar 0,120 untuk data fungi $T$. mentagrophytes dan fungi $C$. albicans diperoleh nilai signifikan lebih besar dari 0,05 yaitu sebesar 0,279 , data homogen telah memenuhi syarat uji ANOVA dan uji lanjut menggunakan uji lanjut Tukey.

\section{Pengujian Secara Kromatografi Lapis Tipis (KLT)}

Hasil penampang bercak kromatografi lapis tipis menunjukkan hasil positif mengandung alkaloid setelah disemprot dengan pereaksi bouchardat ditandai dengan terbentuk warna coklat pada plat KLT. Pembuatan pereaksi buouchardat iodin bereaksi dengan ion I- dari kalium iodida menghasilkan ion $\mathrm{I}^{3-}$ yang berwarna coklat. Uji bouchardat ion $\mathrm{K}^{+}$ akan membentuk ikatan kovalen koordinat dengan nitrogen pada alkaloid membentuk kompleks kaliumalkaloid yang mengendap [11].

Hasil penampang bercak kromatografi lapis tipis pada pereaksi amoniak menunjukkan hasil positif flavonoid karena terbentuknya warna jingga setelah pereaksi disemprotkan pada plat KLT. Hasil pereaksi tanin warna yang terbentuk pada plat KLT menunjukkan warna hitam, perubahan warna pada plat ini menunjukkan hasil positif senyawa tanin didalam fraksi etanol ekstrak kulit durian. Perubahan warna ini karena terbentuknya senyawa kompleks tanin dengan logam Fe. Senyawa kompleks terbentuk karena adanya ikatan kovalen koordinasi antara ion atau atom logam dengan atom non logam [12].

Hasil uji dengan pereaksi libermanbouchardat untuk uji saponin menunjukan hasil negatif pada reaksi warna karena tidak terbentuk warna ungu pada plat KLT, setelah dilakukan uji pendahuluan dengan uji busa menunjukkan hasil positif ditandai dengan busa yang bertahan lebih dari 10 menit. Perhitungan rf diperoleh nilai sebesar 0,76, sedangkan pada penelitian terkait baku pembanding saponin menggunakan saponin murni diperoleh nilai if sebesar 0,8 . Nilai if yang diperoleh pada penelitian ini mendekati nilai rf tersebut [13] penelitian ekstrak kulit durian yang telah dilakukan ekstrak kulit durian positif mengandung senyawa metabolit sekunder saponin [2]. Timbulnya busa menunjukkan adanya glikosida yang mempunyai kemampuan membentuk buih dalam air yang terhidrolisis menjadi glukosa dan senyawa lainnya. 
Bercak noda pada plat KLT yang diperoleh setelah penyemprotan $\mathrm{FeCl}_{3}$ untuk senyawa tanin diperoleh nilai if sebesar 0,58 penelitian terkait identifikasi senyawa tanin pada daun kemuning diperoleh nilai rf 0,6 dan pada penelitian daun sirsak didapatkan nilai rf sebesar 0,56 . Nilai if pada penelitian ini untuk senyawa tanin mendekati nilai rf kedua penelitian tersebut maka dapat disimpulkan bahwa pada fraksi etanol ekstrak kulit durian positif mengandung senyawa tanin dipertegas dengan reaksi warna yang berubah menjadi warna hitam [14].

Nilai rf alkaloid yang diperoleh dari fraksi etanol ekstrak kulit durian yaitu 0,64 . Berdasarkan harbone nilai rf yang paling umum adalah pada kisaran 0,07-0,62 nilai rf yang diperoleh tidak termasuk dalam golongan alkaloid paling umum namun pada identifikasi bercak melalui penyemprotan terbentuk warna coklat menunjukkan bahwa fraksi etanol mengandung senyawa alkaloid [15].

Pereaksi amoniak yang digunakan untuk uji flavonoid diperoleh nilai rf yaitu 0,7 pada penelitian uji kemampuan produksi flavonoid dari benalu teh menunjukkan nilai if flavonoid yaitu 0,68 dan 0,69 yang termasuk kedalam flavonoid kuersetin. Penelitian fraksi etanol ekstrak kulit durian nilai rf mendekati nilai rf kuersetin dan identifikasi warna menunjukkan warna jingga, dapat disimpulkan bahwa fraksi etanol ekstrak kulit durian mengandung senyawa flavonoid golongan kuersetin [16].

Senyawa metabolit sekunder pada fraksi etanol ekstrak kulit durian yaitu senyawa flavonoid, tanin, alkaloid dan saponin. Senyawa flavonoid berperan penting dalam interkelasi atau ikatan hidrogen dengan senyawa kompleks dari protein ekstraseluler dan terlarut sehingga merusak membran sel fungi dan diikuti dengan keluarnya senyawa intraseluler [17]. Mekanisme antifungi alkaloid yaitu dengan bekerja menghambat enzim yang berperan dalam replikasi DNA. Inhibisi replikasi DNA menyebabkan fungi tidak dapat melakukan pembelahan sehingga menghambat pertumbuhan fungi. Interaksi antara senyawa saponin dengan dinding sel mengakibatkan rusaknya dinding sel dan membran sel hingga akhirnya dinding dan membran sel fungi lisis [17]. Senyawa tanin memiliki aktivitas antifungi dengan cara menghambat sintesis kitin yang digunakan untuk pembentukkan dinding sel pada fungi dan merusak membran sel sehingga pertumbuhan fungi terhambat [18].

\section{Pengujian Secara KLT-Bioautografi}

Metode ini didasarkan atas difusi senyawa yang telah dipisahkan dengan kromatografi lapis tipis (KLT). Pengujian antifungi terbukti bahwa fraksi etanol ekstrak kulit durian memiliki aktivitas sebagai antifungi untuk kemudian dapat dilakukan uji bioautografi untuk mengetahui senyawa yang paling aktif dalam menghambat fungi $T$. mentagrophytes dan C.albicans. Hasil dari uji bioautografi adalah terdapat zona bening pada $3 \mathrm{~cm}$ lempeng media yang telah digambar untuk fungi $T$. mentagrophytes dan C.albicans terdapat zona bening pada $3.5 \mathrm{~cm}$.

Nilai $\mathrm{Rf}$ yang diperoleh T.mentagrophytes yaitu 0,6 , nilai rf bioatografi mendekati nilai rf senyawa tanin yaitu 0,58 , ini disebabkan karena mekanisme kerja senyawa tanin yaitu cara menghambat sintesis kitin yang digunakan untuk pembentukkan dinding sel pada fungi dan merusak membran sel sehingga pertumbuhan fungi terhambat [18]. 
Zona bening pada uji KLT bioautografi fungi uji $C$. albicans diperoleh nilai rf yaitu 0,7 , nilai rf bioatografi $C$. albicans dibandingkan dengan nilai rf bercak KLT sama dengan nilai if senyawa aktif flavonoid. Mekanisme kerja flavonoid sebagai antifungi yaitu senyawa flavonoid berperan penting dalam interkelasi atau ikatan hidrogen dengan senyawa kompleks dari protein ekstraseluler dan terlarut sehingga merusak membran sel fungi dan diikuti dengan keluarnya senyawa intraseluler.

\section{Uji Konsentrasi Hambat Minimum (KHM)}

Konsentrasi hambat minimum (KHM) adalah konsentrasi terendah dari suatu zat uji yang dapat menghambat pertumbuhan fungi uji. Uji KHM dilakukan pada konsentrasi terendah yang memberikan zona hambat pada fungi uji. Konsentrasi terendah yang memberikan zona hambat pada media SDA yaitu konsentrasi $10 \%$ terhadap fungi $T$. mentagrophytes maupun $C$. albicans. Uji KHM parameter yang digunakan yaitu dengan melihat kekeruhan pada media SDB dengan fungi uji dan zat uji yang telah ditambahkan.

Uji KHM dilakukan pada beberapa konsentrasi yaitu mulai dari $1 \%-9 \%$. Larutan didalam tabung reaksi mulai jernih menandakan pertumbuhan kedua fungi mulai terhambat oleh fraksi etanol dari ekstrak kulit durian. Fraksi etanol ekstrak kulit durian terhadap pertumbuhan fungi $T$. mentagrophytes dilihat dari kekeruhannya menghasilkan nilai konsentrasi $\mathrm{KHM}$ yaitu sebesar $7 \%$ dan bersifat fungistatik ditandai dengan adanya pertumbuhan fungi pada media SDA. Fungi uji $C$. albicans menghasilkan nilai KHM pada konsentrasi $8 \%$ dan bersifat fungistatik.

\section{Kesimpulan}

Berdasarkan penelitian yang telah dilakukan pada penelitian ini dapat disimpulkan bahwa :

1. Fraksi etanol ekstrak kulit durian memiliki aktivitas antifungi terhadap T. mentagrophytes dan C.albicans

2. Fraksi etanol ekstrak kulit durian positif mengandung senyawa flavonoid, tanin, saponin dan alkaloid yang mempunyai aktivitas antifungi, senyawa aktif yang paling efektif menghambat pertumbuhan fungi $T$. mentagrophytes yaitu tanin dengan nilai if 0,6 . dan senyawa yang paling efektif menghambat pertumbuhan fungi C.albicans yaitu flavonoid dengan nilai rf 0,7.

3. Konsentrasi hambat minimum fraksi etanol kulit durian untukfungi $T$. mentagrophytes yaitu pada konsentrasi $7 \%$, untuk fungi C.albicans pada konsentrasi $8 \%$, keduanya bersifat fungistatik.

\section{Saran}

Berdasarkan penelitian yang telah dilakukan, maka penelitian lebih lanjut disarankan untuk pengujian antifungi menggunakan fraksi lain dan isolasi senyawa antifungi.

\section{UCAPAN TERIMAKASIH}

Terimakasih untuk Ketua laboratorium FMIPA, Prodi Farmasi Universitas Tulang Bawang (Bapak Isbiantoro, S.Si.,Apt.) dan staf yang telah mengijinkan dan membantu peneliti menyeleseikan penelitian ini. 


\section{DAFTAR PUSTAKA}

[1] N. Arlofa, "Uji Kandungan Senyawa Fitokimia Kulit Durian sebagai Bahan Aktif Pembuatan Sabun," Chemtechhemtech, vol. 1, no. 1, pp. 18-22, 2015.

[2] H. Setyowati, H. Z. Hanifah, and R. P. Nugraheni, "Krim Kulit Buah Durian (Durio zibethinus L.) Sebagai Obat Herbal Pengobatan Infeksi Jamur Candida albicans," MFI, vol. 8, no. 2, pp. 1-7, 2013.

[3] Tjay and K. Rahardja, Obatobat Penting. Jakarta: PT.Elex Media Komputindo, 2002.

[4] K. Irianto, Mikrobiologi Medis (Medical Microbiology). Bandung: alfabeta, 2013.

[5] Muhaimin, "Isolasi dan Karakterisktik Senyawa Bioaktif Antijamur Trichophyton mentagrophytes Penyebab Penyakit Kurap dari Biji Buah Biraksa (Cassia Fistula L.).," Ind. Soc. Integ. Chem, vol. 6, no. 2, 2014.

[6] S. Juariah and S. Wahyuni, "Efektivitas Ekstrak Kulit Durian (Durio zibethinus L.) Sebagai Penghambat Pertumbuhan Trichophyton mentagrophytes," J. Anal. Kesehat., no. August, 2017.

[7] D. K. RI, Parameter Standar Umum Ekstrak Tumbuhan Obat. Jakarta: departemen kesehatan RI, 2000.

[8] B. . Lay, Analisis Mikroba di Laboratorium. Jakarta: PT. Grafindo Persada, 1994.

[9] E. Kusumaningtyas, Estie Astuti, and Darmono, "Sensitivitas Metode Bioautografi Kontak Dan Agar Overlay Dalam Penentuan
Senyawa Antikapang," Junal IImu Kefarmasian Indones., vol. 6, no. 2, pp. 75-79, 2008.

[10] Voigt, Buku Pelajaran Teknologi Farmasi. Yogyakarta: Gajah Mada Univercity Press., 1994.

[11] A. Maliana, "Aktivitas Antioksidan Ekstrak Etanol Daun Andong (Cordiline fruticosa (L) A. (Cheval)," Mulawarman Sci., vol. 11, no. 1, p. 1412-498X, 2012.

[12] Effendy, Perspektif Baru Kimia Koordinasi Jilid I, I. Malang: Banyu Media Publishing, 2007.

[13] D. S. Sopianti and D. W. Sary, "Skrining Fitokimia Dan Profil KLT Metabolit Sekunder Dari Daun Ruku-ruku (Ocimum tenulflorum L.) Dan Daun Kemangi (Ocimum sanctum $L$ )," SCIENTIA, vol. 8, no. 1, pp. 4452, 2018.

[14] G. G. Kusumo, M. A. H. F. F, and $H$. Asroriyah, "Identifikasi Senyawa Tanin Pada Daun Kemuning ( Murraya panicullata L . Jack ) Dengan Berbagai Jenis Pelarut Pengekstraksi," J. Pharm. Sci., vol. 2, no. 1, pp. 29-32, 2017.

[15] Harbone, Metode Fitokimia" Penuntun Cara Analisis, 2nd ed. Bandung: Institut Teknologi Bandung, 1987.

[16] J. A. Priyanto, S. Pujiyanto, and I. Rukmi, "Flavonoids Production Capability Test of Tea Mistletoe ( Scurrula atropurpurea BL . Dans ) Endophytic Bacteria Isolates Jurnal Sains dan Matematika," JSM, vol. 22, no. 4, pp. 89-96, 2014.

[17] Ernawati and K. Sari, "Kandungan Senyawa Kimia 
Dan Aktivitas Antibakteri

Ekstrak Kulit Buah Alpukat

(Persea americana P.Mill)

Terhadap Bakteri Vibrio

alginolyticus," J. Kaji. Vetiriner,

vol. 3, no. 2, pp. 203-211, 2015.

[18] W. Christoper, D. Natalia, and

S. Rahmayanti, "Artikel

Penelitian Uji Aktivitas Antijamur

Ekstrak Etanol Umbi Bawang

Dayak ( Eleutherine americana (

Aubl .) Merr . Ex K . Heyne .)

terhadap Trichophyton

mentagrophytes secara In

Vitro," J. Kesehat. Andalas, vol.

6, no. 3, pp. 685-689, 2017. 
Jurnal Farmasi Lampung ～～～Vol 8. №. 1 Juni 2019 